\title{
Patterns of avian malaria in tropical and temperate environments: testing the "The enemy release hypothesis"
}

\author{
Yasmine Antonini ${ }^{1 *}$ (D), Debora Nogueira Campos Lobato ${ }^{1}$, Ana Cláudia Norte ${ }^{2}$, Jaime A. Ramos ${ }^{2,3}$, \\ Patrícia de Abreu Moreira ${ }^{1}$ \& Erika Martins Braga ${ }^{4}$ \\ ${ }^{1}$ Universidade Federal de Ouro Preto, Departamento de Biodiversidade Evolução e Meio Ambiente, \\ Ouro Preto, $M G$, Brasil \\ ${ }^{2}$ Universidade de Coimbra, MARE - Centro de Ciências do Mar e do Ambiente, Coimbra, Portugal \\ ${ }^{3}$ Universidade de Coimbra, Faculdade de Ciências e Tecnologia, Departamento de Ciências da Vida, \\ Coimbra, Portugal \\ ${ }^{4}$ Universidade Federal de Minas Gerais, Instituto de Ciências Biológicas, Departamento de Parasitologia, \\ $M G$, Brasil \\ *Corresponding author: Yasmine Antonini, e-mail: antonini.y@gmail.com
}

ANTONINI, Y., LOBATO, D.N.C., NORTE, A. C., RAMOS, J. A., MOREIRA, P.A., BRAGA E. M. Patterns of avian malaria in tropical and temperate environments: testing the "The enemy release hypothesis". Biota Neotropica. 19(4): e20180716. http://dx.doi.org/10.1590/1676-0611-BN-2018-0716

\begin{abstract}
According to the enemy release hypothesis (ERH) the spread of invasive species will be facilitated by release from their enemies as they occupy new areas. However, the ERH has rarely been tested by comparing populations of native (non-invasive, long established) species with expanding or shifting ranges, to the same species as invasive in another area. We tested the ERH with respect to blood parasite levels (prevalence and intensity of Plasmodium spp. and Haemoproteus spp.) of (a) two closely related, widely distributed species of thrush (Turdus leucomelas and T. merula), and (b) an invasive sparrow (Passer domesticus) whose range has expanded from the Old World to the New World since the $18^{\text {th }}$ century. A total of 158 birds were sampled in Portugal and 99 in Brazil. All bird species were parasitized, and $55 \%$ of the individuals collected were parasitized, and the mean intensity of infection was of 28 parasites per 10,000 erythrocytes. We assessed whether differences in levels of infection (prevalence and intensity) were due to site (tropical/New World and temperate/Old World) or host species. The ERH was supported: Passer domesticus and Turdus merula had higher levels of parasitism in the Old World than in the New World. Thus, $P$. domesticus seems to be benefitting from its "recent" range expansion, compared to T. leucomelas, through ecological release from its native parasites and because the parasites of the recently invaded area seem to be infesting native species instead.
\end{abstract}

Keywords: Portugal, Brazil, Turdus, House sparrow, invasive bird, range expansion.

\section{Padrões de malária aviária em região tropical e temperada: testando a "hipótese da liberação do inimigo"}

Resumo: De acordo com a hipótese da liberação do inimigo (HLI), a disseminação de espécies invasoras será facilitada pela liberação de seus inimigos ao ocuparem novas áreas. No entanto, a HLI raramente é testada comparando-se as populações de espécies nativas (não invasivas, estabelecidas há muito tempo) que apresentam expansão ou alteração de habitats, com populações das mesmas espécies em habitats que foram invadidos. Testamos a HLI com relação aos níveis de parasitas no sangue (prevalência e intensidade de Plasmodium spp. e Haemoproteus spp.). De (a) duas espécies estreitamente relacionadas e amplamente distribuídas de Turdus (Turdus leucomelas e T. merula), e (b) um pardal invasor (Passer domesticus) cujo alcance se expandiu do Velho Mundo para o Novo Mundo desde o século 18. Um total de 158 aves foram amostradas em Portugal e 99 no Brasil. Todas as espécies foram parasitadas e $55 \%$ dos indivíduos foram parasitados, sendo que a intensidade média da infecção foi de 28 parasitas por 10.000 eritrócitos. Avaliamos se as diferenças nos níveis de infecção (prevalência e intensidade) foram devidas ao local (tropical/Novo Mundo e temperado/Velho Mundo) ou espécies hospedeiras. A HLI foi corroborada: Passer domesticus e Turdus merula apresentaram valores mais elevados de parasitismo no Velho Mundo do que no Novo Mundo. Assim, P. domesticus parece estar se beneficiando de sua expansão "recente" em comparação com $T$. leucomelas, através da liberação ecológica de seus parasitas nativos porque os parasitas da área recentemente invadida parecem infestar espécies nativas.

Palavras-chave: Portugal, Brasil, Turdus, pardal, ave invasora, expansão de habitat. 


\section{Introduction}

Avian Haemosporidian infections is caused by blood parasites of the phylum Apicomplexa, which includes the genera Plasmodium, Haemoproteus, Leucocytozoon and Fallisia (Valkiūnas 2005). Parasites of the genus Plasmodium causes avian malaria and are transmitted by mosquitoes of the family Culicidae, while parasites of the genus Haemoproteus are transmitted by flies of the families Hippoboscidae and Ceratopogonidae (Santiago-Alarcon et al. 2012). Plasmodium and Haemoproteus infections have negative consequences to host fitness by reducing clutch sizes and nest defense behavior, increasing probability of clutch desertion, reducing hatching and fledging success and weaning nestlings with poorer body condition (Korpimaki et al. 1993, Dulfa 1996, Hakkarainen et al. 1998, Sanz et al. 2004, Andrezj 2005, Marzal et al. 2005). They also pose a physiological cost to the host birds (Norte et al. 2009, Dallas et al. 2016), and may ultimately lead to death (Warner 1968, Cannell et al. 2013, Vanstreels et al. 2014).

Due to climatic stability, it has been predicted that parasite pressure should be greater in tropical than temperate species since parasites and their vectors can persist throughout the year (Janzen 1970, Connell 1971). However, most avian studies have found the opposite pattern (Ricklefs 1992, Martin et al. 2007), with greater Haemosporidian prevalence in birds from temperate areas than those from tropical areas. Therefore, the Enemy Release Hypothesis (ERH) could help explain the success of temperate avian species introduced into tropical regions in relation to their blood hemoparasites (Lima et al. 2010, Marzal et al. 2011). The ERH states that the abundance and distribution of an invasive species will be facilitated by the absence of natural enemies in the new habitats (Keane \& Crawley 2002). Thus, we expected that colonizers or exotic populations will have competitive advantages due to lower parasite loads and consequently better health conditions than endemic populations. According to Marzal et al. (2011), range shifts of host or parasite species may result in species interactions not previously experienced in the wild. Consequently, introduced species might encounter novel parasites whose virulence will partly determine whether they become invasive.

Only a few studies have tested the role of Haemosporidian parasites in invasive birds by comparing their prevalence in invasive birds living in temperate and tropical environments (Marzal et al. 2011), and they have generally produced inconclusive results. For example, the prevalence of Haemosporidian parasites did not differ significantly between populations of the common myna, Acridotheres tristis, in India (Ishtiaq et al. 2006) compared to an invasive population in Australia (Clark et al. 2015), whereas parasite prevalence in house sparrows in their native range was higher when compared to those introduced to central Brazil (Lima et al. 2010, Marzal et al. 2011). Small sample sizes were recognized as the main reason for these inconsistent conclusions because other variables, such as age, sex and body condition, can also influence parasite prevalence.

We used microscopy and PCR to examine the prevalence of avian Haemosporidian parasites in populations of two thrush species (Turdus) and the house sparrow (Passer domesticus) that inhabit tropical and temperate environments. We focused on addressing three questions: (1) Do Haemosporidian prevalence and density differ between host species? (2) Do Haemosporidian prevalence and density differ between populations of the same host species/genus, sampled in temperate (Western Europe, Portugal) and tropical (South America, Brazil) environments? (3) Does Haemosporidian infection cause negative consequences to host health in both temperate and tropical areas?

In testing the potential contributions of the Enemy Release Hypothesis to explain the prevalence and intensity of infection, we hypothesize that Turdus spp. and P. domesticus will have greater Haemosporidian infection and parasitemia in birds sampled from their historical range (Europe) compared to birds sampled in their recent range (Brazil). Furthermore, we hypothesize that infected "invasive" birds will have a better health condition than those infected in their native area.

\section{Material and Methods}

\section{Bird species}

The study was conducted with three bird species: the house sparrow Passer domesticus, the Pale-breasted thrush Turdus leucomelas and the Eurasian blackbird T. merula. Over the last two centuries, and with human assistance, the house sparrow has spread to all continents (except Antarctica) and many oceanic islands (Summers-Smith 1988). It expanded its range into South America during the 18th century, reaching Brazil in the same century, according to Efe et al. (2001). The avian genus Turdus is one of the largest and most widely distributed passerine genera, with 65 recognized extant species occurring throughout South America, Central and North America, Africa, and Eurasia; one species (Turdus merula) has been introduced to Australia. This is one of the few genera of passerines that has radiated extensively both in Africa, South America, and the Palearctic and Oriental regions (Clement \& Hathway 2000, Collar 2005). The Eurasian blackbird is a species of true thrush that breeds in Europe, Asia, and North Africa, and was introduced to the Americas in the beginning of $20^{\text {th }}$ century. The pale-breasted thrush is also a species of true thrush, and is found in a wide range of wooded habitats in eastern and northern South America, with localized populations in the West (Nylander et al. 2008). According to Nylander et al. (2008) Turdus merula and T. leucomelas shares a common ancestor.

\section{Study area and sampling}

The study was carried out during both the breeding and nonbreeding seasons between May 2008 and February 2010 in Brazil (House sparrows in state of Minas Gerais and Pale-breasted thrush in Tocantins) and March and November 2010 in Portugal (Coimbra and Baixo Mondego, Eurasian blackbird and House sparrow) (Figure 1).

Birds were captured using mist-nets and banded with a metallic ring provided by Centro de Pesquisa para a Conservação de Aves Silvestres and Instituto Chico Mendes de Conservação da Biodiversidade (CEMAVE/ICMBio) in Brazil and Centro de Estudos de Migrações e Proteção de Aves and Instituto da Conservação da Natureza e das Florestas (CEMPA/ICNF) in Portugal. Approximately $50 \mu \mathrm{L}$ of blood was collected from each individual through puncture of the brachial vein using a disposable hypodermic needle and microcapillary tubes. Measured morphometric characters included body weight, which was measured with spring scales (Pesola AG from Switzerland) with a precision of $0.1 \mathrm{~g}$, and tarsus length, measured with a digital calliper to the nearest $0.01 \mathrm{~mm}$. To evaluate host health, body condition was calculated using the residuals from the regression of body weight on tarsus length (Brown 1996). All collected samples were tested by microscopic and PCR-based methods in parallel. 


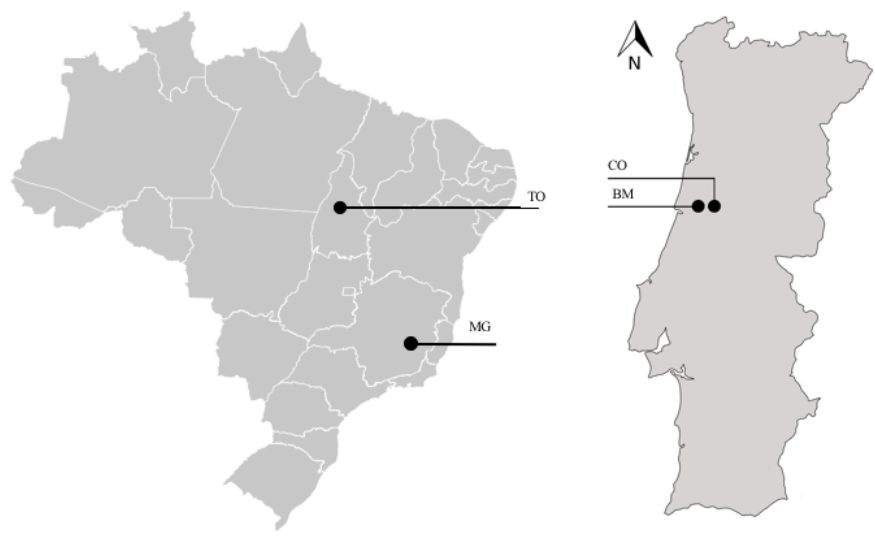

Figure 1. Study areas in Brazil: TO-Tocantins, MG-Minas Gerais and Portugal CO-Coimbra, BM-Baixo Mondego Region.

\section{Microscopic analyses}

Three blood smears were prepared per bird for identification of the morphological stages of Haemosporidian parasites. Blood smears were air-dried, fixed in absolute methanol and stained with $10 \%$ Giemsa. A minimum of 100 fields was examined at high magnification $(1000 \mathrm{x})$ and the parasite intensity (i.e. parasitemia or density) was calculated by counting the number of infected erythrocytes per 10,000 erythrocytes (Godfrey et al. 1987, Valkiūnas 2005). Parasites (Plasmodium and Haemoproteus) were identified microscopically according to the morphological characteristics of the different blood stages (Valkiūnas 2005).

\section{DNA extraction and screening}

The remaining blood, after microscopic analyses, was immediately transferred into new sterile microtubes, with and without heparin, containing $300 \mu \mathrm{L}$ of cell lysis solution (Promega, MA, EUA) for DNA extraction.

Genomic DNA was extracted from bird blood samples using Wizard Genomic DNA Purification Kit (PROMEGA ${ }^{\circledR}$, Madison, Wisconsin, USA) according to the manufacturer's protocol. In order to determine Haemosporidian infection, 50 to $100 \mathrm{ng}$ of the extracted DNA was used for a screening PCR that amplifies a 154 nucleotide segment of ribosomal RNA coding sequence within the mitochondrial DNA of Plasmodium and/or Haemoproteus in a single reaction. We used the primers 343F (5' GCTCACGCATCGCTTCT 3') and 496R (5' GACCGGTCATTTTCTTTG 3') according to the protocol described by Fallon et al. (2003). The positive control consisted of genomic DNA from Plasmodium gallinaceum (obtained from experimentally infected chickens) and negative controls were DNA samples obtained from non-infected chickens maintained at the Veterinary School (UFMG). The overall prevalence of Haemosporidian infection was considered as the proportion of individuals infected, in each population of each species/region, based on the combination of the results of microscopic examination of blood smears and PCR analysis.

\section{Statistical analyses}

To investigate if there were any differences in the prevalence and infection intensity of avian malaria and body condition between house sparrows and thrushes from Brazil and Portugal, generalized linear mixed models (GLMM) were constructed considering a binomial error distribution and logit link function for infection prevalence and quasi-poisson error distribution for infection intensity. In order to account for non-independence due to capture, random effects included individuals and location, and fixed effects included site (Portugal and Brazil), host species (Passer domesticus - BR and PT, Turdus merula and T. leucomelas), sex (Male and Female) age (Juvenile and Adult). To investigate if there were differences in the Haemosporidian infection on body condition, were constructed a model using parasitized and non-parasitized birds species from Brazil and Portugal as explanatory variables and body condition as response variable.

GLMM was used because it allowed us to pool all bird species by using individual infection status (infected or not) as the dependent variable, while controlling for sample size difference. Thus, information is not lost due to sample size restrictions, since more weight will be given to data with larger sample sizes (Paterson \& Lello 2003, Jovani $\&$ Tella 2006). In addition, GLMM is a powerful method for analyzing parasitological data because it allows for the analyses of binomial data while controlling for correlations between measures that occur as a result of grouped observations (Paterson \& Lello 2003). We used software R for all analyses (R Development Core Team 2016).

\section{Results}

A total of 257 adult birds were captured: 40 house sparrows and 59 pale-breasted thrushes in the tropical region of Brazil and 66 House sparrows and 92 Eurasian blackbirds in the temperate region of Portugal. Taking into account all bird species in both regions, the total parasite prevalence was $55 \%$ and the mean parasite intensity was 27.96 parasites/10,000 erythrocytes. Plasmodium spp. and Haemoproteus spp. were detected. Haemoproteus spp. were found both in Turdus merula and $P$. domesticus in temperate region and only in Turdus leucomelas in Tropical region. Plasmodium and Haemoproteus prevalence in the temperate region (Portugal $=49 \%$ and $12 \%$ respectively) were higher than in the tropical region (Brazil $=37 \%$ and $10 \%$ ) (Table 1 ).

Even when we analyzed bird species separately, this regional pattern remained the same. Trophozoites were the predominate form and were observed in all positive blood smears. Since these forms (Trophozoites) are not present in Haemoproteus parasites in blood smears, Plasmodium parasites were found in all the samples.

Other forms, such as meronts and gametocytes, were occasionally observed only in slides prepared from birds inhabiting temperate areas.

Prevalence and intensity were significantly higher in both House sparrows and thrushes from the temperate region when compared to birds from the tropical region $\left(\mathrm{F}_{2,257}=4.44, \mathrm{P}=0.036\right.$ and $\mathrm{F}_{2,257}=5.34$, $\mathrm{P}=0.002$; Figure $2 \mathrm{~A}$ and $\mathrm{B}$ ). Thrushes were significantly more infected $\left(\mathrm{F}_{2,257}=5.54, \mathrm{P}=0.032\right)$ and had a higher mean parasite intensity than house sparrows $\left(\mathrm{F}_{1,257}=3.15, \mathrm{P}=0.004\right)$ in both regions (Figure $2 \mathrm{~A}$ and $\mathrm{B})$. Sex and age were not good predictors for Haemosporidian infection because we found no significant differences in the prevalence and intensity of infection between birds of different sex and among birds of different ages.

Haemosporidian infection had a significant influence on the body condition only for birds from the tropical region $\left(\mathrm{F}_{7,257}=79.203, \mathrm{P}<0.001\right.$; Figure 3 ) when comparing positive and negative groups from both regions. 
Antonini, Y. et al.

Table 1. Prevalence and parasite intensity of Plasmodium spp., using combined PCR and microscopy, in bird species from Temperate (Portugal) and Tropical (Brazil) regions. $-\mathrm{TM}=$ Turdus merula $; \mathrm{TL}=$ Turdus leucomelas $; \mathrm{PD}-$ Passer domesticus; $\mathrm{H}=$ Haemoproteus $; \mathrm{P}=$ Plasmodium.

\begin{tabular}{lccccc}
\hline \multirow{2}{*}{ Bird species } & Country & Individuals (n) & Prevalence (\%) & \multicolumn{2}{c}{$\begin{array}{c}\text { Parasite intensity (\%) } \\
\text { (Mean } \pm \text { SE) }\end{array}$} \\
\hline TM & Portugal & 92 & 16.0 & 54.0 & $24.76 \pm 46.75$ \\
PD & Portugal & 66 & 5.0 & 42.0 & $1.43 \pm 2.14$ \\
TL & Brazil & 59 & 10.0 & 40.0 & $1.30 \pm 2.94$ \\
PD & Brazil & 40 & 0.0 & 40.0 & $0.48 \pm 0.64$ \\
\hline Total & & 257 & 9.0 & 91.0 & $27.97 \pm 30.32$ \\
\hline
\end{tabular}

a Prevalency was calculated by counting the number of infected erythrocytes per 10,000 erythrocytes.
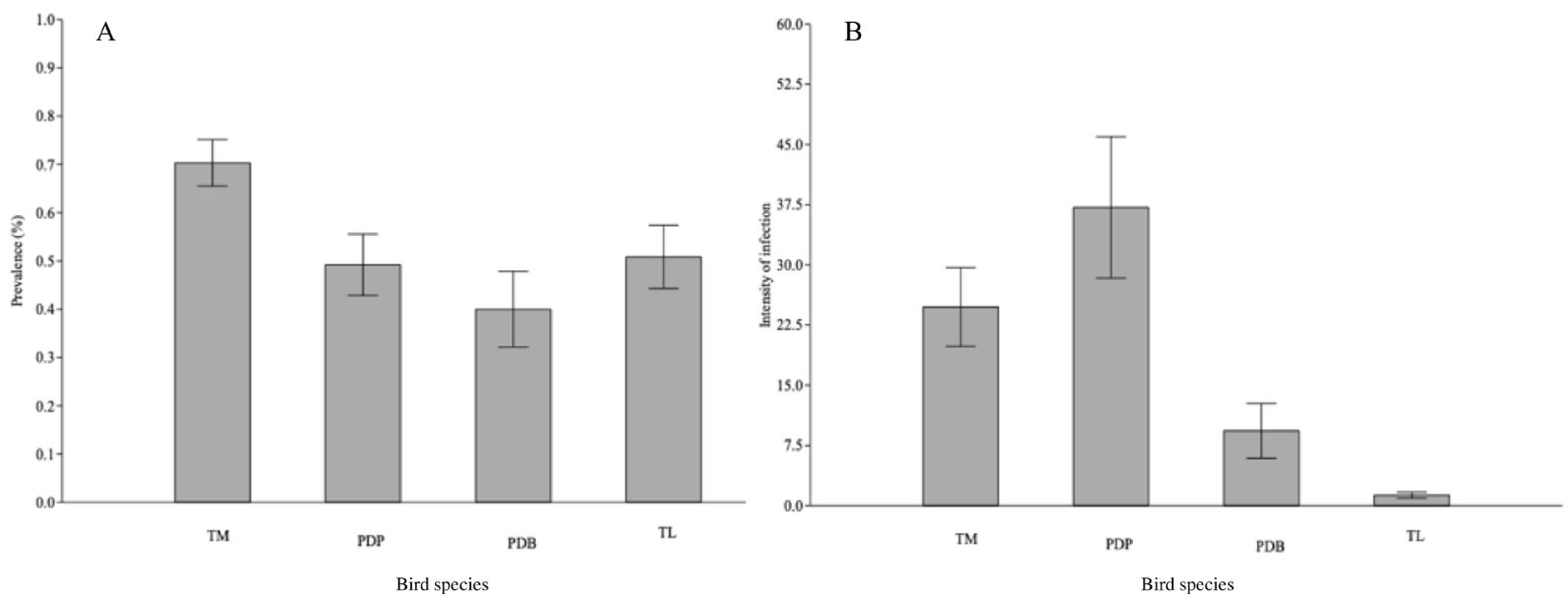

Figure 2. Prevalence (A) and Intensity of infection (B) of Haemosporidian on bird species from Temperate (Portugal) and Tropical region (Brazil) after the combination of PCR and microscopic analysis. TM $=$ Turdus merula, TL $=$ T. leucomelas, PDP: Passer domesticus Portugal, PDB: P. domesticus Brasil. Error bars are mean \pm sd.

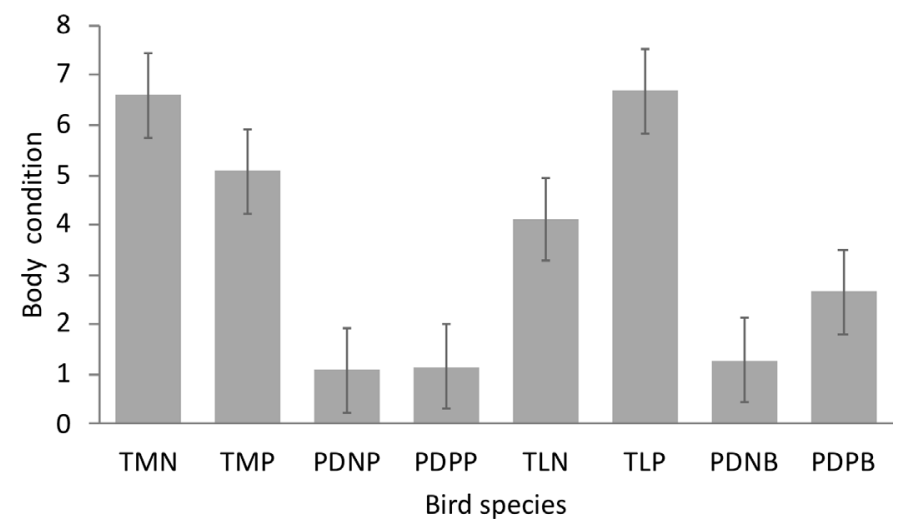

Figure 3. Body condition of positive and negative birds species from Temperate (Portugal) and Tropical region (Brazil). TMN = Turdus merula negative, TMP $=$ Turdus merula positive, TLP $=$ T. leucomelas positive, $T L N=T$. leucomelas negative, PDPP: Passer domesticus positive Portugal, PDNP: Passer domesticus negative Portugal, PDPB: P. domesticus postive Brazil, PDNB: P. domesticus negative Brazil. Error bars are mean \pm sd.

\section{Discussion}

The Enemy Release Hypothesis predicts that a species whose range is expanding should have lower levels of parasitism in 'new' sites versus 'old' sites. Corroborating the ERH, we found that both house sparrows and thrusts in their native range (temperate zone) exhibited a higher prevalence of Haemosporidian infection than in their non-native or range expanding (tropical zone). Similar results were obtained by Marzal et al. (2011), who pointed out that the most common lineage of Haemosporidian parasite, Haemoproteus passeris, was not observed in house sparrows in introduced areas. In addition, we found that $T$. leucomelas had lower Haemosporidian parasite infections than T. merula (the species considered as expanding range). Furthermore, our results support another prediction of the ERH, which is that non-indigenous species in their introduced range should exhibit lower parasite prevalence than in their native range. Indeed, we found that the prevalence and intensity of infection in the House sparrow were lower than those found in the thrush species in both sampled areas (Lafferty \& Holt 2003, Torchin et al. 2003, Lafferty et al. 2005). Although native to Mediterranean areas, the range of the House sparrow has changed considerably. The success of the House sparrow in colonizing novel environments is unquestionably linked to the widespread occurrence of favorable agricultural and urban habitats resulting from human activities. It is important to notice that the main difference on the intensity of infection among the House sparrow from temperate versus tropical region, could be more important, since the difference on prevalence was small, but significant.

This same pattern of parasite infection was found by Ricklefs \& Sheldon (2007) studying Turdus spp. from temperate and tropical zones. Although not significant, they found a Haemosporidian prevalence of $57 \%$ in Turdus migratorius from Missouri and a prevalence of $63 \%$ in this host species from Michigan, whereas the prevalence in Turdus gray from Panama was only $41 \%$. Moreover, they found a significantly higher infection intensity in thrushes from temperate than from tropical 
zones (Ricklefs \& Sheldon 2007). Our results are also in accordance with those of Lima et al. (2010), who found, despite their low sample size for native urban birds, a low prevalence of Haemosporidian in the house sparrow compared to native bird species in Brazil.

Considering the three-bird species together, we found the prevalence of Haemosporidian infection to be significatively higher for the tropical regions compared to tropical ( $70 \%$ and $61 \%$ respectively). Discussion if the prevalence of Haemosporidian are lower in tropical regions, compared to temperate regions are frequent in the literature. Several studies have suggested that Haemosporidian infections are generally less prevalent in the tropics than in temperate regions (Ricklefs 1992, Valkiūnas et al. 2006). A lower prevalence was found in other temperate areas, such as Southeast Mediterranean (42\%, Marzal et al. 2011) and France (41\%, Loiseau et al. 2011), but higher values for prevalence was also found in Southeast and Southwest Europe, with $61.6 \%$ and $52.9 \%$, respectively (Marzal et al. 2011). The total prevalence for the tropical areas of our study was also higher than that found by Lima et al (2010) (20\%), but was similar to that reported by Belo et al. (2011) (55\%) and Lobato et al. (2011) (58\%).

Haemosporidian prevalence for the Eurasian blackbird (70\%) was higher than previously described for this host species, with approximately $31 \%$ in Germany (Geue \& Parteche 2008) and 53\% on the island of São Miguel, Azores (Hellgren et al. 2011). For the Pale breasted thrush, Haemosporidian prevalence (50\%) was also higher than previously described in Brazil (20\% Lima et al. 2010; 23\% (Sebaio et al. 2012), however, it was lower than that described in another study in Brazil (58\% Lobato et al. 2011). For the House sparrow, we also found higher prevalence among Old World birds, while the prevalence in Brazil was higher than that previously described by Lima et al. (2010) and by Marzal et al. (2011). Clearly, parasite prevalence differed drastically between native bird species and populations of the non-native House sparrow on different continents and from different study areas, possibly resulting from different trade-offs between immune function against parasites and other energetically costly activities such as predator defense and competition, among others (Navarro et al. 2004). This finding also supports the idea that prevalence varies geographically and from population to population (Merilä et al. 1995), and could be a result of variation in exposure among localities, which should be related to vector presence, abundance and competence (Bennett et al. 1998, Norte et al. 2009).

In addition to host richness, climatic conditions and lack of suitable vectors could explain the low parasitemia among the House sparrows in Brazil. One hypothesis is that the lower prevalence of blood parasites is due to the lack of suitable vectors for the completion of the parasite's life cycle. However, since native urban bird species were infected with Haemosporidian, it appears that suitable vectors are present in the urban localities where the birds were sampled (Valkiūnas et al. 2006).

Haemosporidian vectors require specific conditions of temperature and humidity to complete their life cycle (Hopp \& Foley 2001). Although Portugal has lower mean temperatures and pluviosity than Brazil, temperate environments have higher thermal variation throughout the year, with distinct seasons and high temperatures only during summer, resulting in an increase in vectors during this period. However, tropical environments, where the temperature and rainfall are distributed throughout the year, offer better conditions for maintaining active vector populations that could infect hosts throughout the year. This could explain why we observed trophozoites in most of the samples, even though they are difficult to detect.

Body condition was not a good predictor of Haemosporidian infection since it did not differ between infected and non-infected hosts from the temperate region, and although the differences were greater between infected and non-infected birds from the tropical areas, they were not significant. Other studies also failed to find a relationship between parasitemia and body condition, such as in Ploceus capensis from South Africa (Schultz et al. 2010). Norte et al. (2009), however, found that body condition was related to haemoparasite infection in birds from Portugal. In their study, the body condition index decreased with infection by Leucocytozoon and Plasmodium, but was dependent upon the year and season. The low body condition of the birds in our study could be explained by the large energy expenditure by breeding individuals, followed by the dry season when weather conditions are more adverse. Negative effects of haematozoan infection on body mass are difficult to detect in wild birds that co-evolve with blood parasites (Bennett et al. 1988), and may also be related to food availability throughout the year and/or reproductive period (Schraderet et al. 2003).

The pathogenicity of blood parasites in wild birds has been difficult to demonstrate because of the capacity of the hosts to maintain infections below a threshold at which effects become apparent (Marzal et al. 2005, Norte et al. 2009, Lobato et al. 2011). We show that the house sparrow in non-native regions has a lower prevalence and intensity of haemosporidia infections than in their native range, which is consistent with the ERH. As the ERH is still controversial, more detailed comparative studies of house sparrows, as well as other bird species, and their malaria parasites and co-existing host species in native and non-native ranges are necessary to shed light on these important questions and to better understand the impact of invasive species on the biodiversity of the invaded communities.

"Parasite prevalence" refers to the proportion of a host population that is infected, which is traditionally measured by visual inspection of blood smears (Godfrey et al. 1987, Valkiūnas 2005). However, prevalence data have not been compared broadly with adequate control for host taxonomy. Moreover, prevalence might be confounded by immune response to the extent that it reflects the ability of host individuals to control chronic infections below the level of detection by visual examination of blood smears. Thus, the present study has contributed to a better understanding of variation in haematozoa prevalence and ecology in host bird species of two genus, in two geographic regions.

\section{Acknowledgments}

We thank, Alexandre Magno Enout, Paulo Tenreiro and Pedro Miguel Araujo for help with fieldwork. This study was financially supported by FAPEMIG - APQ-05914-07. We thank CNPQ for a scholarship to Yasmine Antonini, Debora Lobato and Erika Martins Braga. This study was financially supported by FCT through the strategic program of MARE (MARE - UID/MAR/04292/2013) and the fellowships to Ana Cláudia Norte (SFRH/BPD/62898/2009 and SFRH/BD/13594/2003). 


\section{Author Contributions}

Yasmine Antonini: Contributed to data analysis and interpretation, manuscript preparation and critical revision; Contributed to data collection.

Debora Nogueira Campos Lobato: Contributed to data analysis and interpretation, manuscript preparation and critical revision; Contributed to data collection.

Ana Cláudia Norte: Contributed to data analysis and interpretation, manuscript preparation and critical revision; Contributed to data collection.

Jaime A. Ramos: Contributed to data analysis and interpretation, manuscript preparation and critical revision.

Patrícia de Abreu Moreira: Contributed to data analysis and interpretation, manuscript preparation and critical revision.

Erika Martins Braga: Contributed to data analysis and interpretation, manuscript preparation and critical revision.

\section{Conflicts of interest}

The authors declare that they have no conflict of interest related to the publication of this manuscript.

\section{References}

ANDREZJ, D. 2005. Male reproductive success is correlated with blood parasite levels and body condition in the promiscuous aquatic warbler (Acrocephalus paludicola). Auk 122(2):558-565

BELO, N.O., PINHEIRO, R.T., REIS, E.S., RICKLEFS, R.E. \& BRAGA, E.M. 2011. Prevalence and lineage diversity of avian haemosporidians from three distinct cerrado habitats in Brazil. PLOS ONE 6(3):e17654.

BENNETT, G.F., CAINES, J. \& BISHOP, M.A. 1988. Influence of blood parasites on the body mass of Passeriform birds. J. Wildlife Dis. 24(2):33943.

BROWN, M.E. 1996. Assessing body condition in birds. In Current Ornithology. (V. Nolan \& E.D. Ketterson, eds.). Springer, Boston, p.67-135.

CANNELL, B.L., KRASNEC, K.V., CAMPBELL, K., JONES, H.I., MILLER, R.D. \& STEPHENS, N. 2013. The pathology and pathogenicity of a novel Haemoproteus spp. infection in wild Little Penguins (Eudyptula minor). Vet. Parasitol. 197(1-2):74-84.

CLARK, N.J., OLSSON-PONS, S., ISHTIAQ, F. \& CLEGG, S.M. 2015. Specialist enemies, generalist weapons and the potential spread of exotic pathogens: malaria parasites in a highly invasive bird. Intl. J. Parasitol. 45(14):891-899.

CLEMENT, P. \& HATHWAY, R. 2000. Thrushes. Christopher Helm/A \& C Black, London.

COLLAR, N. 2005. Family Turdidae (thrushes). In Handbook of birds of the world (J. del Hoyo, A. Elliot, D.A. Christie, eds.) Lynx Edicions, Barcelona, p.514-807.

CONNELL, J.H. 1971. On the role of natural enemies in preventing competitive exclusion in some marine animals and in rain forest trees. In: Dynamics of Populations: Proceedings of the Advanced Study Institute on Dynamics of Numbers in Populations (P.J. den Boer \& G.R. Gradwell, eds.) Centre for Agricultural Publication and Documentation, Wageningen, p. 298-312.

DALLAS, T., HOLTACKERS, M. \& DRAKE, J.M. 2016. Costs of resistance and infection by a generalist pathogen. Ecol. Evol. 6(6):1737-1744.

DULFA, R. 1996. Blood parasites, health, reproductive success, and egg volume in female Great Tit Parus major. J. Avian Biol. 27(1):83-87.

EFE, M. A.; MOHR, L. M. \& BUGONI, L. 2001. Guia ilustrado das aves de Porto Alegre. Porto Alegre, PROAVES, SMAM, COPESUL, CEMAVE. 144p.
FALLON, S.M., RICKLEFS, R.E., SWANSON, B.L. \& BERMINGHAM, E. 2003. Detecting Avian Malaria: an improved polymerase chain reaction diagnostic. J. Parasitol. 89(5):1044-1047.

GEUE, D. \& PARTECKE, J. 2008. Reduced parasite infestation in urban Eurasian blackbirds (Turdus merula): a factor favoring urbanization? Can. J. Zoolog. 86(12):1419-1425.

GODFREY, R.D.Jr., FEDYNICH, A.M. \& PENCE, D.B. 1987. Quantification of hematozoa in blood smears. J. Wildlife Dis. 23(4):558-565.

HAKKARAINEN, H., ILMONEN, P., KOIVUNEN, V. \& KORPIMAKI, E. 1998. Blood parasites and nest defense behavior of Tengmalm's owls. Oecologia.114(4):574-577.

HELLGREN, O., KRIZANAUSKIENE, A., HASSELQUIST, D. \& HASSELQUIST, S. 2011. Low Haemosporidian diversity and one key-host species in a bird malaria community on a mid-atlantic island (São Miguel, Azores). J. Wildlife Dis. 47(4):849-859.

HOPP, M. \& FOLEY, J. 2001. Global-scale relationships between climate and the dengue fever vector, Aedes aegypti. Climatic Change 48(2-3):441-463.

ISHTIAQ, F., BEADELL, J.S., BAKER, A.J., RAHMANI, A.R., JHALA, Y.V. \& FLEISCHER, R.C. 2006. Prevalence and evolutionary relationships of haematozoan parasites in native versus introduced populations of common myna Acridotheres tristis. P. R. Soc. B. 273(1586):587-594.

JANZEN, D. 1970. Herbivores and the number of tree species in tropical forests. Am. Nat. 104(940):501-528.

JOVANI, R. \& TELLA, J.L. 2006. Parasite prevalence and sample size: misconceptions and solutions. Trends Parasitol. 22(5):214-218.

KEANE, R.M. \& CRAWLEY, M.J. 2002. Exotic plant invasions and the enemy release hypothesis. Trends Ecol. Evol. 17(4):164-170.

KORPIMAKI, E., HAKKARAINEN, H. \& BENNETT, G.F. 1993. Blood parasites and reproductive success of Tengmalm's owls: detrimental effects on females but not on males? Funct. Ecol. 7(4):420-426.

LAFFERTY, K.D. \& HOLT, R.D. 2003. How should environmental stress affect the population dynamics of disease? Ecol. Lett. 6(7):654-664.

LAFFERTY, K.D., SMITH, K.F., TORCHIN, M.E., DOBSON, A.P. \& KURIS, A.M. 2005. The role of infectious diseases in natural communities: what introduced species tell us. In Species invasions: insights into ecology, evolution, and biogeography (D.F. Sax, J.J. Stachowicz \& M.S. Gaines, eds.). Sinauer Associates, Inc. Publisher, Sunderland, p. 111-134.

LIMA, M.R., SIMPSON, L., FECCHIO, A. \& KYAW, C.M. 2010. Low prevalence of haemosporidian parasites in the introduced house sparrow (Passer domesticus) in Brazil. Acta Parasit. 55(4):297-303.

LOBATO, D.N.C., BRAGA, E.M., BELO, N.O. \& ANTONINI, Y. 2011. Hematological and parasitological health conditions of the Pale-breasted Thrush (Turdus leucomelas) (Passeriformes: Turdidae) in southeastern Brazil. Zoolog. 28(6):771-776.

LOISEAU, C., ZOOROB, R., ROBERT, A., CHASTEL, O., JULLIARD, R. \& SORCI, G. 2011. Plasmodium relictum infection and MHC diversity in the house sparrow (Passer domesticus). P. R. Soc. B. 278(1709):1264-1272.

MARTIN, L.B., PLESS, M.I. \& WIKELSKI, M.C. 2007. Greater seasonal variation in blood and ectoparasite infections in a temperate than a tropical population of House Sparrows Passer domesticus in North America. Ibis. 149(2):419-423

MARZAL, A., LOPE, F., NAVARRO, C. \& MØLLER, A.P. 2005. Malarial parasites decrease reproductive success: an experimental study in a passerine bird. Oecologia. 142(4):541-545

MARZAL, A., RICKLEFS, R.E., VALKIŪNAS, G., ALBAYRAK, T., ARRIERO, E., BONNEAUD, C. et al. 2011. Diversity, loss, and gain of malaria parasites in a globally invasive bird. PLOS ONE 6(7):e21905.

MERILÄ, J., BJÖRKLUND, M. \& BENNETT, G.F. 1995. Geographic and individual variation in haematozoan infections in the greenfinch, Carduelis chloris. Can. J. Zool 73(10):1798-1804

NAVARRO, C., DE LOPE, F., MARZAL, A. \& MØLLER, A.P. 2004. Predation risk, host imune response, and parasitism. Behav. Ecol. 15(4):629-35 
NORTE, A.C., ARAÚJO, M.M., SAMPAIO, H.L., SOUSA, J.P. \& RAMOS, J.A 2009. Haematozoa infections in a great tit Parus major population in Central Portugal: relationship with breeding effort and health. Ibis. 151(4):677-688.

NYLANDER, J.A.A., OLSSON, U., ALSTROM, P. \& SANMARTEÍN, I. 2008. Accounting for phylogenetic uncertainty in biogeography: a bayesian approach to dispersal-vicariance analysis of the Thrushes (Aves: Turdus). Syst. Biol. 57(2):257-268.

PATERSON, S. \& LELLO, S. 2003. Mixed models: getting the best use of parasitological data. Trends Parasitol. 19(8):370-375.

R DEVELOPMENT CORE TEAM. R: A language and environment for statistical computing. R Foundation for Statistical Computing. http://www.R-project. org/. (last access in 03/07/2016).

RICKLEFS, R.E. 1992. Embryonic development period and prevalence of avian blood parasites. Proc. Nat. Acad. Sci. 89(10):4722-4725.

RICKLEFS, R.E. \& SHELDON, K.S. 2007. Malaria prevalence and whiteblood-cell response to infection in a tropical and in a temperate thrush. Auk. 124(4):1254-1266.

SANTIAGO-ALARCON, D., PALINAUSKAS, V. \& SCHAEFER, H.M. 2012. Diptera vectors of avian haemosporidian parasites: untangling parasite life cycles and their taxonomy. Biol. Rev. 87(4):928-964.

SANZ, J.J., MORENO, J., MERINO, S. \& TOMÁS, G. 2004. A trade-off between two resource- demanding functions: post-nuptial molt and immunity during reproduction in male Pied Flycatchers. J. Anim. Ecol. 73(3):441-447.

SCHRADER, M.S., WALTERS, E.L., JAMES, F.C. \& GREINER, E.C. 2003. Seasonal prevalence of a haematozoan parasite of red-bellied woodpeckers (Melanerpes carolinus) and its association with host condition and overwinter survival. Auk. 120(1):130-137.
SCHULTZ, A., UNDERHILL, L.G., EARLE, R.A. \& UNDERHILL, G. 2010. Infection prevalence and absence of positive correlation between avian haemosporidian parasites, mass and body condition in the cape weaver Ploceus capensis. Ostrich. 81(1):69-76

SEBAIO, F., BRAGA, E.M., BRANQUINHO, F., FECCHIO, A. \& MARINI, M.A. 2012. Blood parasites in passerine birds from the Brazilian Atlantic Forest. Rev. Bras. Parasitol. 21(1):7-15.

SUMMERS-SMITH, J.D. 1988. The Sparrows: a study of the genus Passer. 1 ed. T. \& A. D. Poyser Ltd., Calton.

TORCHIN, M.E., LAFFERTY, K.D., DOBSON, A.P., MCKENZIE, V.J. \& KURIS, A.M. 2003. Introduced species and their missing parasites. Nature. 421(6923):628-630.

VALKIŪNAS, G., BENSCH, S., IEZHOVA, T.A., KRIZANAUSKIENĖ, A., HELLGREN, O. \& BOLSHAKOV, C.V. 2006. Nested cytochrome $b$ polymerase chain reaction diagnostics underestimate mixed infections of avian blood haemosporidian parasites: microscopy is still essential. J. Parasitol. 92(2):418-422.

VALKIŪNAS, G. 2005. Avian malaria parasites and other haemosporidia. 1 ed. CRC press, Washington.

VANSTREELS, R.E.T., KOLESNIKOVAS, C.K.M., SANDRI, S., SILVEIRA, P., BELO, N.O., FERREIRA-JUNIOR, F.C., EPIPHANIO, S., STEINDEL, M., BRAGA, E.M. \& CATÃO-DIAS, J.L. 2014. Outbreak of avian malaria associated to multiple species of Plasmodium in Magellanic Penguins undergoing rehabilitation in Southern Brazil. PLOS ONE 9(4):e94994.

WARNER, R.E. 1968. The role of introduced diseases in the extinction of the endemic Hawaiian avifauna. Condor. 70(2):101-120.

Received: $12 / 12 / 2018$

Revised: 21/06/2019

Accepted: 01/08/2019

Published online: 09/09/2019 